Check for updates

New York

Cite this as: $B M J 2020 ; 370: m 3110$ http://dx.doi.org/10.1136/bmj.m3110 Published: 6 August 2020

\section{Covid-19: Mental health and economic problems are worse in US than in other rich nations}

\author{
Janice Hopkins Tanne
}

Covid-19 has caused mental health problems, economic hardship, and lack of trust in national leadership among about a third of US adults, higher rates than in nine other high income countries, a survey by the Commonwealth Fund shows. ${ }^{1}$

The private foundation's president, David Blumenthal, a coauthor of the report, said, "People in other countries are living a different, better, reality. Americans should realise that our country can do better, too. We can start by ensuring everyone can get and afford the healthcare they need, and by implementing public health measures such as mask wearing, social distancing, and robust testing and tracing that can help us stop covid-19, as so many others have effectively accomplished.”

He said the pandemic was a unique time to make these comparisons because all countries were facing the same crisis at the same time.

The Commonwealth Fund is a non-profit foundation that supports health policy reform and a high performance health system.

Reginald Williams II, lead author of the report and a fund vice president, said, "In the US the pandemic has taken a greater toll on people's wellbeing when compared with other high income countries.” He said that as cases and deaths continued to increase, US policymakers "should look abroad for innovative solutions."

Clear, consistent messages about the pandemic, with avoidance of politicising and coordination of testing, provision of supplies, and contact tracing, were needed to combat the pandemic, said Eric Schneider, a coauthor and fund vice president.

People in all the countries surveyed reported positive views of how healthcare workers had responded.

As at 5 August the US had 4818328 cases of covid-19 and 157930 deaths. The incidence is more than 50000 new cases a day. ${ }^{2}$

The Commonwealth Fund conducted a survey or a representative sample of 8259 adults in the US and nine other countries from March to May this year: Australia, Canada, France, Germany, the Netherlands, New Zealand, Norway, Sweden, and the UK.

Blumenthal said that, if the survey were conducted now, he thought the US problems would only grow, especially if Congress did not act to help unemployed people and those facing eviction. The US had only $4 \%$ of the world's population but $20 \%$ to $25 \%$ of cases and deaths, he said.

People's trust in their government's response to the pandemic was lowest in the US, where $51 \%$ reported they trusted their state government but only 33\% said they trusted the federal government led by Donald Trump. Trust in the national government was highest in Germany (95\%) and New Zealand (89\%), both of which have managed to control the pandemic relatively well. In the UK $73 \%$ reported trust in the national government and $49 \%$ in local government.

A third of Americans reported stress, anxiety, or great sadness that they found difficult to cope with, the survey found. By comparison, in other countries $26 \%$ of residents, or less, reported problems with stress and anxiety.

Getting mental healthcare was a problem for Americans and UK residents. Some $31 \%$ of US and $32 \%$ of UK residents said they were not able to get help from a professional when they needed it. In contrast, 54\% of Australians and $47 \%$ of Canadians said they were able to get mental healthcare.

Economic consequences fell hardest on Americans. Some 31\% said they were unable to pay for food, heat, or rent, had used up most or all of their savings, had borrowed money, or had taken out a loan. The lowest numbers reporting economic hardship were in the Netherlands (7\%) and Germany (6\%). In the UK $18 \%$ reported economic hardship.

Americans, Australians, and Canadians were most likely to say they had lost a job because of the pandemic. Some 50 million Americans have lost their jobs, and many have applied for unemployment insurance. ${ }^{3}$ Other nations have supported employers so that people kept their jobs.

The US does not have universal healthcare. Instead, health insurance is often tied to employment, so losing a job means losing health insurance. Even people who have health insurance face additional out-of-pocket costs, called co-payments and deductibles, leading some to avoid care because of the potential cost. 
Americans who have lost their jobs may be eligible for unemployment insurance payments from the state they live in, and this was supplemented until 31 July by additional support from the federal government. Discussions continue in Washington, DC, about possibly expanding federal support for unemployed people.

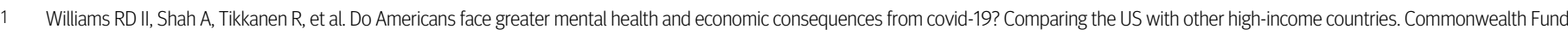
6 Aug 2020. https://www.commonwealthfund.org/publications/issue-briefs/2020/aug/americans-mental-health-and-economic-consequences-COVID19.

2 COVID-19 Dashboard by the Center for Systems Science and Engineering (CSSE) at Johns Hopkins University. (JHU). https://gisanddata.maps.arcgis.com/apps/opsdashboard/index.html\#/bda7594740fd40299423467b48e9ecf6.

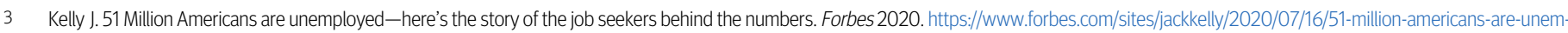
ployedheres-the-story-of-the-job-seekers-behind-the-numbers/\#6ed341616ac1.

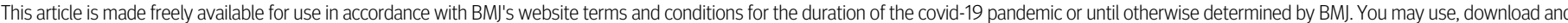
print the article for any lawful, non-commercial purpose (including text and data mining) provided that all copyright notices and trade marks are retained. 